\title{
The Idea of Wilderness
}


This page intentionally left blank 


\section{MAX OELSCHLAEGER}

\section{The Idea of Wilderness}

From Prehistory to

the Age of Ecology 
Copyright 0 I 99 I by Yale University.

All rights reserved.

This book may not be reproduced, in whole or in part, including illustrations, in any form (beyond that copying permitted by Sections 107 and 108 of the U.S. Copyright Law and except by reviewers for the public press), without written permission from the publishers.

Designed by Barbara E. Williams.

Set in Sabon type by Tseng Information Systems, Inc.

Printed in the United States of America.

\section{Library of Congress Cataloging-in-Publication Data}

Oelschlaeger, Max.

The idea of wilderness: from prehistory to the age of ecology / Max Oelschlaeger.

p. $\mathbf{c m}$.

Includes bibliographical references and index.

ISBN 978-0-300-05370-8

r. Human ecology-Philosophy. 2. Wilderness areas. 3. ManInfluence on nature. 4. Philosophy of nature. I. Title.

GF21.034 1991

$333.78^{\prime} 2-\mathrm{dc20} \quad 90-46016$

CIP

A catalogue record for this book is available from the British Library.

The paper in this book meets the guidelines for permanence and durability of the Committee on Production Guidelines for Book Longevity of the Council on Library Resources. 
For Clarence J. Glacken,

both example and inspiration 
This page intentionally left blank 